\title{
THE IMPLEMENTATION OF SCIENTIFIC APPROACH IN BUILDING STUDENTS' CRITICAL THINKING SKILLS THROUGH TEACHING THE SUBJECT OF ISLAMIC EDUCATION AND CHARACTER BUILDING AT SMK NEGERI 1 BOJONEGORO
}

\author{
Muhamad Ansorul Hakim ${ }^{1}$, Zainuddin Maliki \\ ansorulhakim@gmail.com¹ ${ }^{1}$ zainuddin_M@gmail.com²
}

\begin{abstract}
This research discusses how the implementation of scientific approach influences in building students' critical thinking skills on the subjects of Islamic Education and Character building at SMK Negeri 1 Bojonegoro. A combination method called concurrent embedded strategy is used in this research in which quantitative method is used as the primary method and qualitative method is used as the secondary method. The population in this study are 1440 students at SMK Negeri 1 Bojonegoro. Meanwhile, three classes (93 students) of Accounting major in grade $\mathrm{XI}$ are the subject of the research. Purposive sampling is used as sampling technique. Data are collected by using observation, interview, questionnaires, and documentation techniques. The data are analyzed by statistic product moment. The result of research showed that $r_{X Y}=0,404$, when it consulted with $r$ value in table for $\mathrm{N}=93$, with significance level $5 \%=0,202$ and $1 \%=0,263$. So in a significance level of $5 \%$ the $r_{X Y}$ value is greater than the $r_{t}$ value, and in a significance level of $1 \%$ the $r_{X Y}$ value is also greater than the $r_{t}$ value. When it consulted with the amount of " $\mathrm{r}$ " product moment, there is a moderate correlation of the interpretation of variables $\mathrm{X}$ and variable $\mathrm{Y}$. In conclusion, there is a moderate correlation between the implementation of scientific approach and critical thinking skills building on the subjects of Islamic Education in SMK Negeri 1 Bojonegoro.
\end{abstract}

Keywords: Implementation, Scientific Approach, Critical Thinking Skills.

\section{Introduction}


In the national regulation of Indonesia number 20 year 2003 about the National Education System, Education is a conscious and planned effort to create an atmosphere of learning and learning process so that learners actively develop their potential to have spiritual religious power, self-control, personality, intelligence, excelence attitude, and skills needed for himself, society, nation and state. ${ }^{1}$

To achieve these goals, eight national education standards are establised. The national standards of education are competency passing-grade standards, content standards, process standards, infrastructure standards, educator and education personnel standards, management standards, financing standards and assessment standards. ${ }^{2}$

In the regulation of the Ministry of Education and Culture number 65 year 2013 on The Process Standards mention that every educator in the educational institution is obliged to develop a complete and systematic lesson plan (RPP) for interactive, inspirational, fun, and challenging learning to motivate the learners actively participate, and provide sufficient space for initiative, creativity, and independence in accordance with the talents, interests, and physical and psychological development of learners. ${ }^{3}$

In the national regulation number 20 year 2003 on the National Education System, Article 37 paragraphs 1 and 2 affirms that the curriculum content of each type, course and level of education shall contain religious education, civic education, language, mathematics, natural sciences, social sciences, art culture, physical education and sports, skills or vocational, and local content. ${ }^{4}$

The Regulation of the Ministry of Education and Culture number 59 year 2014 in Annex III explains that the learning process that must be done by the teachers of Islamic Education (PAI) is to conduct learning by using scientific approach. ${ }^{5}$

\footnotetext{
${ }^{1}$ National Educational Department of Indonesia, Undang-Undang RI Nomor 20 Tahun 2003 Tentang Sistem Pendidikan Nasional (Jakarta: Educational Department, 2003), Ed. I, 6.

${ }^{2}$ Government Regulation No.32 year 2013 on the change of PP (government regulation) number 19 year 2005 about the standard of National Education (state paper of the Republic of Indonesia year 2013 number 71 , additional State paper).

${ }^{3}$ Permendikbud (Regulation of ministry of Education and Culture) number 65 year 2013 about the curriculum of secondary school (SMA/MA).

${ }^{4}$ National Educational Department of Indonesia, Undang-Undang RI Nomor 20 Tahun 2003 Tentang Sistem Pendidikan Nasional (Jakarta: Educational Department, 2003), Ed. I, 36.

${ }^{5}$ Permendikbud number 59 year 2014 about the curriculum of secondary school (SMA/MA)
} 
Scientific learning is a learning adopted the steps of scientists in building knowledge through scientific methods. The required learning model is the one that enables the improvement of critical thinking skills, the development of a sense of inquiry, and the creative thinking skills of the students. The required learning model is capable to produce the ability of learning. Scientific learning not only views learning outcomes as the final goals, but the learning process is considered very important $t^{6}$.

In Islamic Education, learning method is a factor that can not be ignored, because it helps to determine the successful of the achievement of Islamic Education. The correlation between the goals and methods of Islamic education is a causal relationship. It means, if the educational method is used properly and appropriately, the educational goals will likely be achieved. ${ }^{7}$

The learning process in principle is a process of religious moral, activity and creativity development of learners through various interactions and learning experiences. However, in its implementation there are, still, many learning activities that ignore the activity and creativity of the learners. This is due to the learning model and system that emphasizes only on the mastery of intellectual ability (Cognitive) and the learning process is centered on the teacher (Teacher Center) where the students just waiting for the description from the teacher, then record and memorize it. ${ }^{8}$

One of life skills needed to be developed in the process of education is the thinking ability. ${ }^{9}$ Thinking ability is the ability of a person who plays a role in determining the success of his life in the future. The importance of thinking in life as the word of Allah Almighty in Surah Ali Imran verses 190-191: It means: "Verily, in the creation of the heavens and the earth, and the turn of the night and the day, there are signs (greatness of Allah) for the intelligent, those who remember Allah while standing, sitting, or lying down, and they are thinking about the creation of the heavens and the earth (and saying), "O our Lord, you have not created all this in vain"

\footnotetext{
${ }^{6}$ Abdul Majid dan Chaerul Rahman, Pendekatan Ilmiah dalam Implementasi Kurikulum 2013 (Bandung: PT. Remaja Rosda Karya, 2015), Ed. II, 3.

${ }^{7}$ Abdul Majid, Pendidikan ..., 76.

${ }^{8}$ Zurinal, Ilmu Pendidikan, Pengantar dan Dasar-Dasar Pelaksanaan Pendidikan (Jakarta: UIN Jakarta Press, 2006), Ed. I, 117-118.

${ }^{9}$ Purwanto Joko, "Efektivitas Model Pembelajaran Inkuiri Tipe Pictorial Riddle Dengan Konten IntegrasiInterkoneksi Pada Materi Suhu Dan Kalor Terhadap Kemampuan Berpikir Kritis Peserta didik SMA", Journal of Physic Education Study Program UIN Sunan Kalijaga, Yogyakarta, 2014.
} 
be holy, protect us from the punishment of hell. "In this verse it is clear that in the order of the heavens and the earth and the beauty of His creation and also alternating day and night regularly throughout the year we feel and as we think of His unity.

Critical thinking is a must in solving problems, making decisions, analyzing assumptions. Critical thinking is applied to train students solving problems in a systematic and innovative way, and design a fundamental solution. By implementing critical thinking, learners analyze what they think, synthesize information, and make a conclusion. Critical thinking can be developed through the learning of Islamic Education and Character subjects because these subjects have complete and clear structure and study between concepts.

The problems arisen during the learning process is the unoptimimalization of critical thinking skills in applied learning system because the learning proces is still a one-way learning so students can only master the materials delivered by teachers, and they are more likely to memorize rather than understanding the concept.

In addition, the lack of ability to formulate own ideas, the lack of courage to express opinions, and the lack of understanding on the learning concept are caused by the lack of students interest and participation, and uneffective strategies and media used in the learning process. This phenomena narrows the mindset of learners about what they learn. This situation causes learners finding it difficult to think critically.

A possible step to overcome this problems is trying to implement a scientific approach. Scientific learning approach can improve the critical thinking skills of learners because learners are trained to observe, question, try, reason and communicate through the learning stages.

Learning through the scientific approach is a learning process designed in such a way that learners actively construct concepts, laws, or principles through observing stages (to identify or find problems), formulate problems, propose or formulate hypotheses, collect data with various techniques, analyze data, draw conclusions and communicate the concepts, laws, or principles found. Learners become the main subject of the scientific approach, learners can actively participate in learning, and provide opportunities for learners to build concepts in knowledge independently, familiarize learners in formulating, dealing with, and solving problems found. Thus, it is expected that learners can improve their understanding of a certain material so 
they are able to think critically. So the implementation of a scientific approach is well suited in forming the learner's critical thinking skills.

Therefore, the researcher interests to conduct research entitled "The Implementation of scientific learning approach in building student critical thinking Ability in Islamic education subject and character building at SMK Negeri 1 Bojonegoro".

\section{Research Methods}

This research uses mixed methods which is a research method that combine qualitative method and quantitative method to be used together in a research activity so the gained data are more comprehensive, valid, reliable and objective ${ }^{10}$ :

Concurrent embedded strategy is used as the research method model.The research method with the combination of concurrent embedded strategy is a research method that combines the use of qualitative and quantitative research methods simultaneously (or vice versa), but the role of each method is different. So there is a primary method and a secondary method. The primary method is used to obtain primary data and secondary methods is used to obtain data to support the obtained data from the primary method. The primary method is quantitative and the secondary method is qualitative.

The purpose of this study is to find out whether there is an effect of the implementation of scientific approach in building students' critical thinking skills on the subjects of Islamic Education and character building. This research is called as correlative research and qualitative phenomenology.

This research model is a correlative research model aimed to find the the correlation of the vaiables, the closeness and the significance of the relationship. To calculate the magnitude of correlation using statistics. The statistical technique used is bivariate coefficient correlation which is a statistic that can be used by researcher to explain the closeness of the correlation between two variables.

There are two variables in this research. They are independent variable (X), variable that influence or become the reason, in this research is scientific approach,

\footnotetext{
${ }^{10}$ Suharsimi Arikunto, Suhardjono, Supardi, Penelitian Tindakan Kelas (Jakarta : Bumi Aksara, 2008), Ed. VI, 16.
} 
and dependent variable (Y), the influenced variables or the result, in this research is critical thinking skills. It can be described as follows:

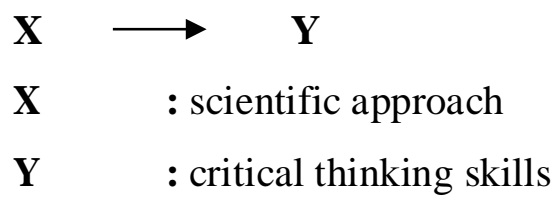

Thus, the research instruments used to collect quantitative data are instrument to measure the scientific approach and instrument to measure critical thinking ability.

The type of data required in this study inlines with the purpose of research, determining the extent of correlation between the implementation of the scientific approach in building students' critical thinking skills on the subjects of Islamic Education and character building at SMK Negeri 1 Bojonegoro. Then, the data are grouped into two, namely qualitative data and quantitative data. The qualitative data are obtained from indicators understood by students and teachers related to scientific approach and critical thinking ability, and from the result of observation in Teaching and Learning Activities. Meanwhile, the quantitative data are obtained from the object of research including the data of students, educators, employees, and school facilities.

The population in this research were 1440 students of SMK Negeri 1 Bojonegoro while the sample is three classes (93 students) of grade X of Accounting major.

Sampling technique used in this research is Purposive sampling done by taking subject based on the existence of certain objectives and considerations. The purpose of this research is to know the influence of the implementation of scientific approach in building students' critical thinking ability at the school. The sample is choosen based on several considerations: (1) Accounting major is the most favorite major in the school, (2) the students has skills above the average, and (3) scientific approach is implemented in the teaching and learning activities.

In this research, quantitative and qualitative data are collected at the same time and alternately in short interval. Besides, the researcher uses several techniques to collect data as follows: 
a. Observation is a method that is done by observing of the object studied. ${ }^{11}$ This method is used to collect data about educational support and fasilities in the school and completeness of facilities and infrastructure of Islamic Religious Education and Character building in the school. This method is used to collect qualitative data as well as to reinforce quantitative data.

b. Interview is a method that is done by communication with data source through dialogue (question and answer) orally, either directly or indirectly. This method is used to know the implementation of scientific approach in teaching and learning activities conducted by teachers and to know the students' understanding in building critical thinking skills after the material given by the teacher through a scientific approach. This method is used to collect qualitative data as well as to strengthen quantitative data.

c. Questionnaire is a technique or way of collecting data indirectly (Researchers do not directly ask questions to respondents). This method is used to collect quantitative data as the primary data. This method is used to prove the hypothesis proposed based on the existing indicators in research variables, namely independent variable containing the implementation of the scientific approach in SMK Negeri 1 Bojonegoro and the dependent variable contains the formation of critical thinking skills of students in SMK Negeri 1 Bojonegoro.

d. Documentation is a method that is done by examining the books, records, files of a problem related to the topic studied. In this case the documentation method used to obtain data about the existence of the school including teachers, staff and students, Curriculum, Lesson Plan (RPP) and photos of teaching and learning activities. In other words, this method is done by investigate the school documentation. This method is used to collect qualitative data as well as to reinforce quantitative data.

This research is a concurrent embedded model, a research combination with quantitative method as primary method and qualitative method as secondary method. Therefore, the quantitative data are analyzed through statistics, the qualitative data

${ }^{11}$ Ibid., 129. 
are analyzed through qualitative methods, and the combined data are analyzed statistically and qualitatively.

To answer the first problem formulation, descriptive statistics and qualitative analysis are used. By using this analysis, it can be calculated how far the implementation of the scientific approach on the subjects of Islamic Education and character building in SMK Negeri 1 Bojonegoro. To answer the formulation of the second problem, descriptive statistics and qualitative analysis are used. By using this analysis, it can be calculated how the formation of critical thinking skills of students of SMK Negeri 1 Bojonegoro is. Next to answer the formulation of the third problem and examine the hypothesis, product moment correlation analysis followed by the calculation of the coefficient of determination (quantitative analysis) is used. Besides, the data will also be analyzed qualitatively including how is the qualitative influence of the implementation model of the scientific approach in building students' critical thinking skills on the subjects of Islamic Education and Character building in SMK Negeri 1 Bojonegoro.

\section{Discussion of Research Results}

The implementation of Scientific Approach on the subjects of Islamic Education and Character building.

a) Lesson Planning

The Islamic Education learning process in Schools should not only emphasizes on the cognitive aspect (memorizing), but also focuses on developing the emotional (affective) and psychomotor (practice) aspect because the content of Islamic Education lessons in schools consists of: Al-Qur'an and Hadith, Aqeedah and Morals, Fiqh, and Islamic History. ${ }^{12}$

Based on the regulation of Ministry of Education and Culture (Permendikbud) Number 65 Year 2013 regarding to Process Standards, lesson planning is designed in the form of Syllabus and Lesson Plan (RPP) which refers to the Content Standards. It includes the arrangement of the Lesson Plans

${ }^{12}$ Ibid., 49. 
and the preparation of media and learning resources, learning assessment, and learning scenarios. ${ }^{13}$

The implementation of a scientific approach in the process of lesson planning of Islamic education can be done by applying scientific principles in learning (observing, asking, gathering information, associating and communicating) supported by learning strategies that enable students to act scientifically such as Discovery Learning, Problem Based Learning, and Project Based Learning. And prepare learning media that support the achievement of Basic Competence.

b) Implementation of Learning

The implementation of scientific approach in Islamic education learning process is linked to the purpose of learning and the basic competences. Islamic activities given at the beginning and the end of the lesson is done by reciting $d h u^{\prime} a$ (pray). Several strategies can be applied in the learning activities with following details:

In the topic of Islamic History, Aqeedaa, and the Quran-Hadith, the implementation of scientific approach is focused on exploring/ gathering information rather than experimenting activities. This is because the characteristics these topics are more likely related to facts and concepts.

$>$ For Fiqh topic, the application of scientific approaches is more focused on experimenting activities than exploring/gathering information. This is because the characteristics of the Fiqh topic are more procedural than factual and conceptual.

In the implementation, all the above topics are supported by various learning models such as: Discovery Learning, Problem Based Learning, and Project Based Learning.

\footnotetext{
${ }^{13}$ Copied of attachment of the regulation of ministry of Education and Culture of the Republic of Indonesia number 65 year 2013 about standard process., 5 .
} 
1) The observation of the process of building a critical thinking skills of students through the Scientific Approach on Islamic Education subjects and character building.

a) Observation is aimed to keep learning closely related to the real situation (context) in everyday life. The process consists of observing, viewing, hearing, reading, and listening the facts or phenomenon/information in the field.

b) Interview is done as one of the process of building students' knowledge in the form of concepts, principles, procedures, legal and theories, until metacognitive thinking. The goal is to have students a high level of critical thinking skills, logical, and systematic. The interview is done through discussion and group work. Group discussion practices provide a space for freedom to express ideas with their own language, including using regional languages.

c) Activities of gathering information is useful to raise the curiosity of students in order to strengthen the understanding of concepts and principles/ procedures by collecting data, developing creativity and procedural skills. These activities include planning, designing, and conducting activities, as well as obtaining, presenting and processing data/ information. The utilization of learning resources including information and communications technology is highly recommended in this activity.

d) The Association Activity is aimed to develop students' think skills and scientific behaviour. The data are classified, processed, and found specific correlations. Activities can be designed by teachers through mock situations for a particular activity so students perform activities such as analyzing, classifying, creating categorizing, summarizing, and predicting/ estimating the data by using discussion sheet or practice.

e) Communicating Activity is a means of delivering conceptualization results in the form of verbal, written, picture/ sketches, diagrams, or graphs. This activity is conducted to enable communicate their knowledge, skills, and its application, as well as their creations through presentations, reports, and performances. 
Building optimal critical thinking skills requires an interactive class. The class should be designed in interesting activity so it can motivate students to involve in the learning process. In the scientific approach, students will act as subjects where students not only as people who are taught but also given freedom of thought and act in order to understand knowledge and solve encountered problems. In addition, students are also given opportunities to find new ways through observation activities because one of the principles of scientific approach is to encourage the development of thinking skills. Thus, students' critical thinking skills can be built through the steps of scientific learning method.

Supporting and Inhibiting Factors in building students' critical thinking skills through the Scientific Approach of Religious Education and Character Education subjects.

\section{a. Supporting Factors}

- Support in term of policy and legal jurisdictional from the government with the issuance of education ministerial laws and regulations on the implementation of the curriculum 2013.

- Support from the government with a large number of trainings on the implementation curriculum 2013 in which also includes the implementation of a scientific approach.

- The availability of learning facilities and infrastructure provided by the government such as teacher books and student books on learning materials of Islamic Education completed with planning, implementation and implementation analysis.

- The Paradigm of curriculum 2013, particularly the scientific approach, is very suitable for this era which focuses on the development of scientific thinking and acting skills.

b. Inhibiting Factors

- Teacher age. Older teachers will find it difficult to adapt to the changing paradigm and mindset of the curriculum 2013. 
- Background of teacher's ability. Scientific approach in its implementation using scientific method will give difficulties for teachers with conventional education background.

- Lack of technology (computer) mastery. The implementation of scientific approaches utilize many sophisticated technology so for teacher and learners who rarely take advantage of technological sophistication will be hampered during the learning process.

- Background of students. For learners who have a low cognitive skills background will experience difficulties in following the learning that implements a scientific approach because in scientific learning is required critical, systematic and logical thinking.

- Lack of instructional media. One of the most important things that can hamper the implementation of scientific approach is the lack of adequate learning media and tools used by teachers in the learning process, where in the scientific approach there is an experiment step.

In analyzing the data, the reseracher uses two approaches, quantitative approaches and qualitative approaches. Quantitative approach is used to analyze each research variable both independent variable (Implementation of Scientific Approach on the Islamic Education and character building subjects) and dependent variable (building critical thinking skills), and to analyze the influence of independent variable to dependent variable. Meanwhile, the qualitative approach is used to analyze matters relating to the situation and condition of SMK Negeri 1 Bojonegoro (Research Area) as supporting data of this research.

Descriptive statistical analysis technique is used to analize the data. The analysis procedure uses two variables, the independent variable $(\mathrm{X})$ with the dependent variable (Y). To investigate the correlation between two variables, statistic product moment analysis technique is used. Then the results will be interpreted in the table of product moment value. So, the conclusion of how far the correlation between those variable will be obtained.

The primary method in this research is quantitative method to analize data obtained from questionnaire. The questionnaire is spread in the form of multiple 
choice which is a statistical model question. The qualitative data needs to be converted into quantitative data by leveling the research interpretation starting from the most correct alternative to the most false alternative. The correct answer has a high score and the wrong answer has a low score. The scoring criteria of alternative answers as follows:

Score 3, choice answer A

Score 2, choice answer B

Score 1 , choice answer C

Of the questionnaire value table data about the implementation model of the scientific approach on the subject of Islamic education and character building above, it can be concluded that the scientific approach model has been implemented well on the subject of Islamic education and character building at SMK Negeri 1 Bojonegoro. This can be seen from the scores as follows: The highest score of each item in the instruments is 3 , the number of instruments is 35 , and the number of respondents is 93 . Thus, the ideal score is $3 \times 35 \times 93=9765$. Furthermore, scores of data obtained from 93 respondents is 8011. It means that the score of the scientific approach implementation on the subject of Islamic education and character building is $8011: 9765=0.820$ or $82 \%$ of the expextation. So, the implementation of the scientific learning approach on the subjects of Islamic education and character building has reached $82 \%$ of the target (with the highest score is $100 \%)$.

Of the data of questionnaire scores table about students' critical thinking skills above, it can be concluded that students' critical thinking skills are well established on the subjects of Islamic education and character building in SMK Negeri 1 Bojonegoro. This can be seen from the scores as follows: the highest score of each instrument item is 3 , the number of instrument is 20 , and the number of respondents is 93 . Thus the ideal score is $3 \times 20 \times 93=5580$. Furthermore, scores of data obtained from 93 respondents is 4339. It means that the score of critical thinking skills of students is $4339: 5580=0.777$ or $77.7 \%$. So, the implementation of the scientific approach on the subjects of Islamic Education and character building has reached $77.7 \%$ of the expected (from the highest score 100).

To know how is the influence of Implementation of Scientific Approach on developing students' critical thinking skills in the subjects of Islamic Education and 
charcter building at SMK Negeri 1 Bojonegoro, the researcher measures the data using the rough numbers of product moment correlation formula with 93 students as the repsondents. The formula to find the correlation index number " $r$ " product moment is as follows:

$$
r_{X Y}=\frac{N \sum X Y-\left(\sum X\right)\left(\sum Y\right)}{\sqrt{\left\{N \sum X^{2}-\left(\sum X\right)^{2}\right\}\left\{N \sum Y^{2}-\left(\sum Y\right)^{2}\right\}}}
$$

The meaning of the statistical symbols above is:

$\sum X Y=$ Sum of multiplication products between variable $\mathrm{X}$ and variable $\mathrm{Y}$

$\sum X=$ Sum of variables $X$ (fasting topic)

$\sum Y=$ Sum of variables $Y$ (character development)

$\mathrm{N}=$ Sum of subjects investigated

$\sum \times 2=$ Sum of squares of variable $\mathrm{X}$

$\sum Y 2=$ Sum of squares of variable $Y$

Furthermore, to find correlation between the implementation of scientific approach and forming students' critical thinking skills on Religious Education subject and Character Building subject as the table above obtained data as follows:

$$
\begin{aligned}
& N=93 \\
& \sum X=8011 \\
& \sum Y=4339 \\
& \sum X Y=375.313 \\
& \sum X^{2}=696.843 \\
& \sum Y^{2}=204.615
\end{aligned}
$$

Then calculate the $r_{X Y}$ score using the following formula

$$
\begin{aligned}
& r_{X Y}=\frac{N \sum X Y-\left(\sum X\right)\left(\sum Y\right)}{\sqrt{\left\{N \sum X^{2}-\left(\sum X\right)^{2}\right\}\left\{N \sum Y^{2}-\left(\sum Y\right)^{2}\right\}}} \\
& r_{X Y}=\frac{93 \times 375.313-(8011)(4339)}{\sqrt{\left\{93.696 .843-(8011)^{2}\right\}\left\{93.204 .615-(4339)^{2}\right\}}} \\
& r_{X Y}=\frac{34.904 .109-34.759729}{\sqrt{\{64.806 .399-64.176 .121\}}\{19.029 .195-18.826 .921\}} \\
& r_{X Y}=\frac{144.380}{\sqrt{\{630.278\}}\{202.274\}} \\
& r_{X Y}=\frac{144.380}{\sqrt{127.488 .852 .172}} \\
& r_{X Y}=\frac{144.380}{357.055,80} \\
& r_{X Y}=0,404
\end{aligned}
$$


Based on the calculation of the above analysis, it is known that the $r_{X Y}$ value is 0.404 , and the $\mathrm{r}$ value for $\mathrm{N}=93$, for the significance level of $5 \%=0.202$ and for the significance level of $1 \%=0.263$.

Thus, the $r_{X Y}$ result is much higher and it means that there is a significant correlation between the Implementation of scientific approach and students' critical thinking skills building in the subjects of Islamic Education and character building in SMK Negeri 1 Bojonegoro both in the level of significance $1 \%$ and $5 \%$.

Considering the $r_{X Y v a l u e}$ with the $r_{t}$ value, it is stated that: for a significance level of $5 \%$ the $r_{X Y}$ value is greater than the $r_{t}$ value, and for a significance level of $1 \%$ the $r_{X Y}$ value is also greater than the $r_{t}$ value. Thus, based on the guidelines of the use of product moment correlation table, the value obtained is significant, between the variables $\mathrm{X}$ (Implementation of the Scientific Approach on the subjects of Islamic Education and Character Building) with variable Y (students' critical thinking skills). There is a positive correlation, both at significance level of $5 \%$ and $1 \%$.

Thus, the $r_{X Y}$ result $=0.404$ in this study is in a moderate correlation and it can be concluded that the implementation of the scientific approach has a moderate effect in building students' critical thinking skills on the subjects of Islamic Education and Character Building at SMK Negeri 1 Bojonegoro. Thus, $H_{a}$ (Hypothesis of work) is accepted and $H_{o}$ (null hypothesis) is rejected. Then, the $H_{a}$ (Hypothesis of work) proposed by the researcher can be proved and proven true.

Qualitative data presented in this study are obtained from the interview, observation and documentation. Sources of information are students and teachers (object of research). Based on the qualitative data, it can be said that: The scientific learning approach on the subjects of Islamic Education and Character building in SMK Negeri 1 Bojonegoro has been implemented well, the teachers have applied the scientific approach with the steps as follows: observing, asking, trying, associating, and communicating. Several learning models suitable to facilitate the implementation of the scientific approach are discovery learning, problem based learning, and project based learning. Students actively follow and express their ideas with critical thinking during those learning process. So, the learning process can activate students' critical thinking skills. This is proven by the number of who students actively ask questions and express critical ideas. 
The scientific approach implemented in teaching Islamic education and character building at SMK Negeri 1 Bojonegoro brings considerable influence in. in the scientific approach, students do self study to find and discover the meaning of the topic then practice it with a enjoying and enthusiastic atmosphere. It is proven by the number of students who are actively asking questions and their critical thinking skills increase by giving various arguments and critical questions from students.

\section{Conclusions}

Having conducted theoretical analyzes by linking and confirming several theories and sources of literature and continued by conducting empirical studies through field research with data collection and calculations through the combination research method (mix method) with concurrent embedded model, conclusion is drawn as follows:

1) The Scientific Learning Approach on the subject of Islamic education and character building in SMK Negeri 1 Bojonegoro has been implemented well based on the result of the research conducted by using various methods of data collection techniques including observation, interview, questionnaire and documentation. This can be seen from the score result as follow: the highest score of each instrument is 3 , the number of instruments is 35 , and the number of respondents is 93 . Thus the ideal score is $3 \times 35 \times 93=9765$. The scores obtained from 93 respondents is 8011 . Thus, the score of the scientific approach on the subject of Islamic education and character building is 8011 : $9765=0.820$ or $82 \%$ of the expectation. So the implementation of the scientific approach on the subjects Islamic education and character building has reached $82 \%$ of the target (with the highest score is $100 \%$ ).

2) The critical thinking skills of students on the subject of Islamic education and character building in SMK Negeri 1 Bojonegoro have been well formed based on the result of the research conducted by using various methods of data collection techniques including observation, interview, questionnaire and documentation. This can be seen from the score result as follow: The highest score of each instrument is 3 , the number of instruments is 20 , and the number of respondents is 93 . Thus, the ideal score is $3 \times 20 \times 93=5580$. The obtained scores from 93 respondents is 4339 . It means that the score of student's critical thinking is 4339: 
$5580=0.777$ or $77.7 \%$ of the expectation. So, the implementation of the scientific approach on the subjects of Islamic education and character building has reached $77.7 \%$ of the target (with the highest score is $100 \%$ ).

3) The implementation of scientific learning approach has a moderate/good influence in building the students' critical thinking skills on the subject of Islamic education and character building in SMK Negeri 1 Bojonegoro. This can be seen on the calculation result by using the product moment correlation coefficient Pearson. The result shows that the $r_{X Y}=0,404$, if consulted with $\mathrm{r}$ score in table for $\mathrm{N}=93$, for significance level $5 \%=0,202$ and for significance level $1 \%=$ 0,263 . So, for significance level $5 \%$, the $r_{X Y}$ score is bigger than $r_{t}$ score, and for a significance level of $1 \%$, the $r_{X Y}$ score is also greater than the $r_{t}$ score. Thus, based on the guidelines of product moment correlation table, the obtained score is significant, between variable $\mathrm{X}$ (implementation of scientific learning approach) and variable Y (students' critical thinking skills), there is a positive correlation, both at the level of significance $5 \%$ and $1 \%$. 


\section{List of References:}

Arikunto, Suharsimi, Suhardjono, Supardi, Penelitian Tindakan Kelas, Jakarta: Bumi Aksara, Ed. VI, 2008.

National Educational Department of Indonesia, Undang-Undang RI Nomor 20 Tahun 2003 Tentang Sistem Pendidikan Nasional, Jakarta: Educational Department, Ed. I, 2003.

Joko, Purwanto, "Efektivitas Model Pembelajaran Inkuiri Tipe Pictorial Riddle Dengan Konten Integrasi-Interkoneksi Pada Materi Suhu Dan Kalor Terhadap Kemampuan Berpikir Kritis Peserta didik SMA ”, Journal of Physic Education Study Program UIN Sunan Kalijaga, Yogyakarta, 2014.

Majid, Abdul dan Chaerul Rahman, Pendekatan Ilmiah dalam Implementasi Kurikulum 2013 (Bandung: PT. Remaja Rosda Karya, Cet.II, 2015.

Government regulation number 32 year 2013 on the change of PP (Government regulation) number 19 year 2005 about the standard of National Education (State Paper of the Republic of Indonesia year 2013 number 71, additional State Paper).

Permendikbud (Regulation of ministry of Education and Culture) number 59 year 2014 about the curriculum of secondary school (SMA/MA) number 65 year 2013 about the standard of educational process in the basic and secondary level.

Copied of attachment of the regulation of ministry of Education and Culture of the Republic of Indonesia number 65 year 2013 about standard process.

Sugiyono, Metode Penelitian Kombinasi (Mixed Methods), Bandung: CV. Alfabeta, Cet. 8, 2016.

Zurinal, Ilmu Pendidikan, Pengantar dan Dasar-Dasar Pelaksanaan Pendidikan, Jakarta: UIN Jakarta Press, Ed. I, 2006. 